\title{
Clinical Characteristics of External Ocular and Periocular Infections and Their Antimicrobial Treatment Patterns Among a Ghanaian Ophthalmic Population; A Multicenter Study
}

Isaiah Osei Duah Junior

Department of Optometry and Visual Science, College of Science, Kwame Nkrumah University of Science and Technology, Kumasi

Michel Pascal Tchiakpe

Department of Optometry and Visual Science, College of Science, Kwame Nkrumah University of Science and Technology, Kumasi

Lawrence Sheringham Borquaye

Department of Optometry and Visual Science, College of Science, Kwame Nkrumah University of Science and Technology, Kumasi

\section{Kwadwo Amoah}

The Eye Clinic, Kumasi South Hospital, Atonsu-Agogo, Kumasi

Francis Kwaku Dzideh Amankwah

Department of Pharmaceutics, Faculty of Pharmacy and Pharmaceutical Sciences, Kwame Nkrumah University of Science and Technology, Kumasi David Ben Kumah

Department of Optometry and Visual Science, College of Science, Kwame Nkrumah University of Science and Technology, Kumasi Linda Aurelia Ofori

Department of Theoretical and Applied Biology, College of Science, Kwame Nkrumah University of Science and Technology, Kumasi

Anthony Danso-Appiah

Department of Epidemiology and Disease Control, School of Public Health, University of Ghana, Legon

Bright Owusu Prempeh

The Anglican Eye Hospital, Jachie

Stephen Yao Gbedema

Department of Pharmaceutics, Faculty of Pharmacy and Pharmaceutical Sciences, Kwame Nkrumah University of Science and Technology, Kumasi Justin Munyaneza

Department of Optometry and Visual Science, College of Science, Kwame Nkrumah University of Science and Technology, Kumasi

Cynthia Amaning Danquah

Department of Pharmacology, Faculty of Pharmacy and Pharmaceutical Sciences, Kwame Nkrumah University of Science and Technology, Kumasi

Kwadwo Owusu Akuffo ( $\square$ koakuffo@gmail.com)

Department of Optometry and Visual Science, College of Science, Kwame Nkrumah University of Science and Technology, Kumasi

\section{Research Article}

Keywords:

Posted Date: January 28th, 2022

DOI: https://doi.org/10.21203/rs.3.rs-1249919/v1

License: () (1) This work is licensed under a Creative Commons Attribution 4.0 International License. Read Full License 


\section{Abstract}

Empirical antimicrobial therapy is linked to a surge in antimicrobial resistant infections. However, an insight on the bacteria etiology of ocular infections is essential in the appropriation of choice of antimicrobial among clinicians, yet there remains a dearth of data from Ghana. We investigated the bacteria etiology of external ocular and periocular infections and antimicrobial treatment patterns among a Ghanaian ophthalmic population. A multicenter study design with purposive sampling approach was employed. Patients demographics and clinical data were collated using a pretested structure questionnaire. Cornea specimens and conjunctival swabs were obtained for bacteriological investigations following standard protocols. About $95 \%$ (98/103) of ocular samples were positive for bacteria culture. The proportion of Gram-negative bacteria was $58.2 \%$, and the predominant bacteria species were Pseudomonas aeruginosa $38.8 \%$ and Staphylococcus aureus $27.6 \%$. Conjunctivitis $40.0 \%$ and keratitis $75.0 \%$ were mostly caused by Pseudomonas aeruginosa. The routinely administered antimicrobial therapy were polymyxin B $41.2 \%$, neomycin $35.1 \%$ and ciprofloxacin $31.6 \%$. Participants demographic and clinical characteristics were unrelated with positive bacteria culture $(p>0.05)$. Our results showed a markedly higher burden of ocular bacterial infections and variations in etiology. Bacterial infection-control and antimicrobial agent management programs should be urgently institutionalized to prevent the emergence of resistant infections.

\section{Background}

Globally, eye infections of bacteria origin remain a significant contributor to ocular morbidity and blindness, and the burden is increasing ${ }^{1,2}$. Further, results from ocular microbial studies across different populations show no obvious pattern in prevalence estimates (ranging from $21.8-82.5 \%$ across Africa ${ }^{2-12}$, Asia $^{13-20}$, Australia ${ }^{21,22}$, Europe $\mathrm{e}^{23-25}$ and North America ${ }^{26}$. Similarly, the bacterial etiology specifically proportion and nature of Gram bacteria as well as the species of bacteria commonly implicated in ocular and periocular infections vary across geographical regions and settings ${ }^{2-13,15-20,22,24-26}$.

Anatomically, the eye is divided into three tunics: the outer (conjunctiva, sclera, cornea), middle (lens, ciliary body, iris), and inner (retina) coats. The tear film contains innate defenses such as bacteriocin, beta-lysin, lipocalin, lysozymes, immunoglobulins ( $\lg \mathrm{A}, \lg \mathrm{G}, \lg \mathrm{M})$, lactoferrins, and with antimicrobial effect against pathogenic strain of microorganisms. The external milieu of the eyes serves as a biome for pathogenic and non-pathogenic organisms. Naturally, antimicrobial constituents within the tear film prevent opportunistic microbes from causing any infections to the eyes. Dysregulation of the homeostatic balance as a result of trauma, contact lens wear, surgery, use of topical antibiotics, and reduced systemic immunity predisposes the eyes to opportunistic pathogens such as bacteria, fungi, virus, and protozoa. However, among these microbes, bacteria are commonly implicated in external ocular and periocular infections ${ }^{27}$. Based on the exterior region affected; external ocular infections can be classified as blepharitis, conjunctivitis, keratitis, dacryocystitis, preseptal and orbital cellulitis ${ }^{28-30}$, thus eyelids, conjunctiva, cornea, lacrimal sac, pre and post-septal areas are respectively involved.

These infections are usually treated with antimicrobial agents with varying modes of action. The gold standard treatment for ocular infections starts with culture and sensitivity testing to identify the causative organism and subsequent administration of narrow-spectrum antibiotic therapy ${ }^{31}$. Consequently, as a results of resource limitation and unavailability of testing facilities most clinicians; including eye care professionals engage in empirical treatments with broad-spectrum antimicrobials ${ }^{32}$. The irrational and prolonged use of broad-spectrum antibiotics in treating eye infections could alter the genetic makeup of ocular bacteria and consequently lead to to antimicrobial resistance ${ }^{33}$.

Ocular antimicrobial resistance is a growing public health threat in both advanced and developing countries. In the developed world nationwide surveillance programs have been institutionalized to monitor ascendancies in the antimicrobial resistance curve and subsequently tackle it. Among these nationwide surveillance programs include Ocular Tracking Resistance in the US Today (Ocular TRUST) ${ }^{34}$, and Antibiotic Resistance Monitoring in Ocular Microorganisms (ARMOR) ${ }^{35}$, European Antimicrobial Resistance Surveillance System ${ }^{36}$, and Swedish Strategic Programme for the Rational Use of Antimicrobial Agents and Surveillance of Resistance ${ }^{37}$. However, in developing countries such as Ghana, aside from the limited accessibility to a national antimicrobial policy, there are compromise regulatory measures and poor adherence to the use of antibiotics ${ }^{38}$.

Multidrug resistance (MDR) is gradually gaining attention in mainstream medicine and public healthcare generally, as it renders antimicrobial agents inefficacious against pathogenic strains of bacteria. MDR causes delays in treatment and recoveries, rise in cost of therapy as well as increase in hospitalization time ${ }^{39-41}$. In a nationwide laboratory based surveillance studies in Ghana, Opintan et al reported over $70 \%$ prevalence of MDR against antibiotics commonly used in treating infections in Ghana ${ }^{42}$. This finding was consistent with studies conducted in the People's Republic of China ${ }^{43,44}$, Italy ${ }^{45}$, and Ethiopia ${ }^{12}$ which showed similar increasing trends. Consequentially, without drastic measures, it is estimated that the world will experience over 10 million annual AMR-related deaths hence it has become imperative to devise ammunitions to curb the situation ${ }^{46}$. Importantly, a decline in ocular MDR will result in increased life expectancy as ocular resistance infections and associated blindness induce mortality.

There is a paucity of data on the prevalence and bacteria etiology of ocular infections in Ghana 9,27. Furthermore, earlier microbiological investigations in Ghana did not exquisitely focus on ocular infections and associated microbes ${ }^{42,47-49}$. The absence of country-specific contemporary estimates limits the modeling of future scenarios, and assumptions with unreliable data and/or making decisions with evidence from other countries is of questionable utility given the geographic differences. An insight on bacteria etiology of ocular infections presented by Ghanaian patients is critical for desirable choice of antibiotic therapy by clinicians. Therefore, the study aims to investigate the bacteria etiology of external ocular and periocular infections, and antimicrobial treatment patterns among a Ghanaian ophthalmic population. The isolates recovered from ocular specimen will aid future antibiotic sensitivity studies and also serve as a gateway for exploration of local medicinal plants as alternative therapeutic agents.

\section{Results}


Table 1 presents the sociodemographic, socioeconomic and healthcare status characteristics of the study participants. Out of the 114 patients presenting with external ocular and periocular infections, majority were females (56.1\%), of median age of 17.0 (Interquartile range; 29.75$)$ years (Table 1 ). The majority of the participants were aged 3-17 years (29.8\%), of Akan tribe ethnicity (93.0\%), and with a protestant religion (80.7\%). Most of them lived in a rural community (59.6\%), with their highest education level being primary (33.6\%) and major occupation as students (43.9\%). An equal proportion were single (21.2\%) and married (21.2\%) and the remaining either cohabiting (3.5\%), divorced (2.7\%), widow (1.8\%) or separated ( $0.9 \%)$. A preponderance of participants never smoked (52.6\%), and with a significantly higher average alcohol intake in males compared to females $(p=0.027)$. Approximately $6 \%$ had hypertension and an equal proportion had diabetes (4.4\%) and peptic ulcer (4.4\%). The number of patients on antihypertensive, antidiabetic and antibiotic medications were $5.3 \%$, $3.5 \%$ and $3.5 \%$, respectively.

\section{Clinical characteristics of external ocular and periocular infections among study participants}

Table 2 shows the clinical characteristics of external ocular and periocular infections among study participants. Most presented with both eyes infected (66.7\%) with the conjunctiva (94.7\%) as the commonest affected site. The majority of the participants had previously used antimicrobials (55.8\%) and have had previous eye infections (45.1\%), and with duration of infection less than one-week (63.7\%). There was a variation between males and females in terms of previous ocular trauma $(p=0.023)$ and previous use of mascara $(p=0.015)$. With respect to monocular visual acuity, majority had right eye visual acuity better than $6 / 18(63.8 \%)$ and with a fewer having visual acuity worse than $6 / 60(2.6 \%)$. Most had a left visual acuity within the ranges $6 / 5-6 / 6(67.5 \%)$ and fewer proportion (1.8\%) having visual acuity better than $6 / 60$ but worse than $6 / 24$. The commonest presenting symptom was hyperemia/redness (69.3\%), followed by discharge, $(62.3 \%)$ itching $(60.5 \%)$, eye pain $(50.9 \%)$ and a smaller fraction having falling lashes ( $0.9 \%)$. Majority received a minimum of two antibiotics for treatment of infections $(40.4 \%)$ and with a fewer portion $(7.9 \%)$ having other treatment other than antibiotics. The proportion of clinical presentations were conjunctivitis (60.5\%), keratoconjunctivitis (11.4\%), blepharoconjunctivis (9.6\%), keratitis (7.9\%), ocular trauma (6.1\%), hordeolum (2.6\%), Preseptal cellulitis ( $0.9 \%$ ) and ophthalmia neonatorum (0.9\%). Other associated conditions were dry eyes (10.5\%), headaches (5.3\%), pterygium (4.4\%) and pinguecula (0.9\%). The commonly used antimicrobial therapeutics were polymyxin B (41.2\%), neomycin (35.1\%) and ciprofloxacin (31.6\%) and fewer instances gentamycin $(2.6 \%)$ and ofloxacin (1.6\%) as shown in Table 3.

\section{Bacteria etiology of extemal ocular and periocular infections among study participants}

One hundred and three (103) ocular specimens were enrolled for bacteriological investigation, 98 (95.1\%) were culture positive, no mixed cultured was identified (Please see Table 3). The proportion of Gram-negative bacteria was $58.2 \%$ with Pseudomonas aeruginosa (38.8\%) and Pseudomonas putida $(11.2 \%)$ being the predominant species. Conversely, the prevalence of Gram-positive bacteria was $41.8 \%$, with a preponderance of bacteria pathogens being Staphylococcus aureus (27.6\%) and Coagulase negative staphylococci, CONS (13.3\%). The commonest strains of bacteria pathogens isolated from conjunctivitis were Pseudomonas aeruginosa (40.0\%), Staphylococcus aureus (21.8\%) and Pseudomonas putida (16.4\%). Similarly, Pseudomonas aeruginosa (41.7\%) and Staphylococcus aureus (33.3\%) were frequently identified in cases of keratoconjunctivitis. Staphylococcus aureus (100.0\%) was the sole organism implicated in cases of preseptal cellulitis, whereas most cases of keratitis was caused by Pseudomonas aeruginosa (75.0\%) as shown in Table 4 .

\section{Factors associated with external ocular and periocular infections}

Table 5. shows logistic regression analyses of the association between patients' demographics, clinical characteristics and prevalence of bacterial infection. None of the factors was significantly associated with prevalence of bacterial infections $(p>0.05)$.

The novel study for the first time aims to investigate the bacteria etiology of external ocular and periocular infections and antimicrobial treatment patterns among a Ghanaian ophthalmic population. About $95 \%$ of the culture were positive for bacteria pathogens, and with the predominant class of bacteria being Gram negatives. Pseudomonas aeruginosa and Staphylococcus aureus were the commonly isolated bacteria species and with the former frequently isolated in cases of conjunctivitis and keratitis. The commonly used antimicrobial therapy in the clinical management of eye infections in these facilities were polymyxin B, neomycin and ciprofloxacin.

Bacteria ocular and periocular infections pose health challenges owing to associated morbidity and blindness. Globally, the burden of bacteria eye infections is higher especially in lower-and-middle income countries including Ghana ${ }^{2-4}$. Though microscopic, the wide biodiversity of bacteria pathogens makes it burdensome for ophthalmic clinicians and physicians when selecting appropriate antibiotic therapy in routine clinical management of ocular and periocular infections. Previously, authors from several geographical jurisdictions have investigated the burden and etiology of bacteria eye infections, however, outcomes from these studies varied considerably $13-15,18,20,25,26$. The prevalence estimates of medical conditions such as bacteria ocular and periocular infections are critical in informing eye care service delivery and in the development of policies to strengthen eye care practices yet there is presently limited ophthalmic data to propagate such transitions within the Ghanaian context. Importantly, gaining insight on bacteria etiology implicated in cases of external ocular and periocular infections within the Ghanaian population is essential to guide clinicians in the appropriate choice of antimicrobial therapy. Nonetheless there is paucity of data in this regard.

Overall, the prevalence of bacteria ocular and periocular infections found in this study was $95.1 \%$. Our results are comparable with studies in Ethiopia ${ }^{50}$, Saudi Arabia ${ }^{51}$, Italy ${ }^{25}$ and United states of America ${ }^{26}$. In a cross-sectional study in Ethiopia, Tesfaye et al. reported a prevalence of $74 \%{ }^{50}$. Similarly, a study by Shahaby and colleagues utilizing participants from a university clinic in Saudi-Arabia found more than two thirds of ocular specimens harboring bacteria pathogens ${ }^{51}$. Likewise, an observational case series conducted in Italy by Papa and coworkers, revealed that the proportion of bacterial infections was estimated at $72.5 \%{ }^{25}$. Furthermore, in a prospective observational study among patients undergoing cataract surgery in the USA, Ta et al. showed that almost eight of every ten ocular specimen obtained from patients eyes had a bacteria etiology ${ }^{26}$. On the one hand, estimates from the present study is significantly 
higher and varies substantially compared to studies in China ${ }^{13,18}$, Iran ${ }^{20}$, South Korea ${ }^{14}$ and Nepal ${ }^{15}$ with prevalence estimates far lower than $50 \%{ }^{13-}$ $15,18,20$. Although geographical settings, study population, seasonality and laboratory procedures could account for such variations as reported earlier, a plausible reason for our observation may be attributable to the fact that our study unlike previous investigations enrolled patients from multiple eye care facilities hence the burden of infections maybe summative. Another reason is that majority of our study participants were rural dwellers with sanitation in such areas usually problematic compared to inhabitants in urban vicinities.

We observed a slightly higher proportion of Gram-negative bacteria compared to Gram positives as etiological agent in our study. This findings contrast with studies from China ${ }^{13}$, Ethiopia ${ }^{11}$, Saudi-Arabia ${ }^{16}$, Uganda ${ }^{4}$ and United States of America ${ }^{26}$ where Gram negatives were found to be significantly lower compared to Gram positive bacteria and with proportional estimates of ranging from six to ten percent $4,11,13,16,26$. Conversely, the proportionate distribution of Gram negatives to positive bacteria found in this study are parallel with results from several existing literatures ${ }^{2,5,8,10}$. For example, among the various ocular microbiology investigations conducted across Ethiopia, by Ayebubizu et al. ${ }^{5}$, Belyhun et al. ${ }^{2}$, Assefa et al. ${ }^{10}$ as well as Getahun and colleagues ${ }^{8}$ the proportionate distribution of Gram-negatives were similar to Gram positives. Of note, whereas the magnitude of Gram-negative bacteria etiology found in Australia ${ }^{21}$, Iran ${ }^{20}$ and Italy ${ }^{24}$ were not equivalent to our findings as well as studies in parts of Ethiopia, the proportion estimates reported were relatively higher. There exist regional variations in the patterns of distribution of Gram-negative bacteria, however, the higher prevalence in our study are ascribed to hygiene as the primary mode of transmission of these enteric bacteria are through oral-fecal contamination. Specifically, we observed during data collection that most patients repeatedly clean ocular discharges with either bare hands or face handkerchief, hence predisposes eyes to contamination by fecal contaminants. Additionally, majority of our study subjects were either in preschool and/or primary hence prone to eye contamination through outdoor gaming activities in school. A considerably higher proportion of the study participants were below two years, and these age categories frequently experience oralocular contamination through inserting hands in mouth and touching of eyes thereafter which may have accounted for the increasingly abundance of Gram negative bacteria than positives in our study.

The predominant bacteria species found in our study were Pseudomonas aeruginosa and Staphylococcus aureus. Although, $S$. aureus was second only to $P$. aeruginosa as the frequently isolated bacteria pathogen, however, it remains the most abundant Gram positive bacteria isolate from all obtainable ocular specimen in our study. This finding are consistent with studies in India ${ }^{19}$, Italy ${ }^{24}$, Nigeria ${ }^{52}$, and Ethiopia ${ }^{4,8,12}$. The occurrence of ocular infections with $S$. aureus etiology may be due to frequent touching of eyes with filthy hands among study subjects. The incidence of Pseudomonas aeruginosa in eye infections are mostly linked with the wearing of contact lens nonetheless we observed an inverse trend in our study. The blinding risk factor associated with Pseudomonas aeruginosa ocular infections underscores the promotion of contact lenses as an alternative to spectacle glasses in vision correction and/or cosmesis. Importantly Pseudomonas aeruginosa are opportunistic pathogens with devastating consequences on the ocular tissues. Specifically, they induce cornea infiltration and ulcerative keratitis when improperly managed by clinicians. Further, the conjunctiva and cornea are in close proximity landmarked by the limbus, hence pathogens of the conjunctiva can easily spread to the cornea during physiological blinking or mechanical rubbing of the eyes. Given the predominance of Pseudomonas aeruginosa in cases of conjunctivitis and keratitis warrants the need for clinicians to probe for other proxy predisposing factors other than relying solely on contact lenses etiology in most instances.

The commonly administered antimicrobial therapy found in this study were Polymyxin B, neomycin and ciprofloxacin. Polymyxin B is a nonribosomal peptidic antimicrobial agents used mostly in the treatment of Gram-negative infections. In particular, they exert their bactericidal effect by binding to phosphate residues within the lipopolysaccharides cell wall to induce displacement of divalent magnesium and calcium cations known to maintain membrane stabilizing properties of Gram-negative bacteria. Consequently, the intrinsic mechanism of action primarily causes an increase in cell membrane permeability resulting in a direct loss of cytoplasmic cell contents. Furthermore, they act synergistically with beta-lactam antibiotics by exposing the peptidoglycan machinery of these Gram negatives for which the latter act on ${ }^{53}$. On the contrary as an aminoglycoside neomycin actively inhibits protein synthesis of bacteria by insurmountably binding to the $16 \mathrm{~S}$ ribosomal RNA as well as $50 \mathrm{~S}$ ribosomal subunits of susceptible class of Gram bacteria ${ }^{54,55}$. Similarly, ciprofloxacin a fluoroquinolone prevents bacteria DNA replication by terminating the action of the reaction enzymes DNA topoimerase IV and DNA gyrase. The ensued effect is suicidal against Gram negatives as well as mixed bacteria culture ${ }^{56}$. Altogether, the frequent use of the aforementioned antibiotic agents in clinical management of ocular and periocular eye infections in our study are concordant with the laboratory results which identified Gram negatives as the predominant bacteria isolates.

Of note, the study has several strengths worth highlighting. The study presents a preliminary and most recent data on bacterial etiology of external ocular and periocular infections among ophthalmic patients in Ghana. Although, we recommend future ocular antibiotic sensitivity studies in this setting, however, in light of the present evidence on the bacterial isolates implicated in eye infection are essential in assisting ophthalmic clinicians in their choice of antibiotic therapy. Moreover, unlike previous studies $2,7,57$ the present investigation utilized sample from multiple sites which underscores the selection bias usually associated with the convenience sampling approach which the study employed. On the contrary, owing to resource limitation the study could not performed direct fluorescent antibody test and/or Giemsa staining to investigate infections of Chlamydia trachomatis etiology. Our prevalence may have been underestimated as a considerable number of our patients where preschoolers whose uncooperative nature denied researchers from taking ocular swabs for bacteriological analyses.

\section{Conclusion}

The prevalence of positive bacteria culture from external ocular and periocular infections was approximately $95 \%$. Gram-negative organisms were commonly implicated and with Pseudomonas aeruginosa and Staphylococcus aureus as the predominant causative bacteria. Clinical presentations of conjunctivitis and keratitis infections were mostly caused by Pseudomonas aeruginosa and with polymyxin B, neomycin and ciprofloxacin as the frequently administered antimicrobial therapy. Given the higher burden of ocular bacterial infections, measures (infections control program and antimicrobial agent management 
program) should be institutionalized to prevent emergence of resistant strains. We recommend future studies to focus on investigating into the potential antibiotic resistances infections within the Ghanaian ophthalmic population.

\section{Methods}

\section{Study design, setting and population}

A multi-center study was conducted among patients suspected of external ocular and periocular infections in three health facilities in Ghana, namely Anglican Eye Hospital, Jachie; St. Michaels Hospital, Pramso; and Kumasi South Hospital, Agogo from July 18, 2021 to September 18, 2021. Cornea scrapings and conjunctival specimens were obtained from infected eyes for bacteriological investigation together with collation of patients sociodemographic and clinical characteristics with a pretested structured questionnaire.

\section{Study setting}

The Anglican Eye Hospital (AEH), St. Michaels Hospital (SMH) and Kumasi South Hospital (KSH) were selected for the study primarily because of their higher out-patient-department (OPD) turnout and the anticipation of meeting our sample size target within the shortest time possible, as well as their wide catchment area and rural/urban interactions. The AEH and SMH are located in Bosomtwe; a rural district in Ghana whilst KSH is situated in the Asokwa municipal area, an urban settlement in the Ashanti Region of Ghana. All the facilities have either a permanent/visiting ophthalmologist, optometrists, ophthalmic nurses and opticians. All the facilities provide comprehensive eye services which range from case history, visual acuity assessment, refraction, dispensing of refractive glasses, management of anterior and posterior segment pathologies, prescribing of medications and performing scheduled surgeries. $\mathrm{SMH}$ and $\mathrm{KSH}$, serve as immediate referral hospitals for the surrounding private and polyclinics. However, all clinical emergencies to the Komfo Anokye Teaching Hospital, the only tertiary health facility in the region. These facilities lack microbiology laboratory hence clinicians employ empirical approaches in their routine diagnosis and management of external ocular and periocular infections.

\section{Study population and sampling}

The study population involved patients who sought ophthalmic treatments/ services for external ocular and periocular infections at the eye clinics of the Anglican Eye Hospital, Jachie; St Michaels Hospital, Pramso; and the Kumasi South Hospital from July 18 to September 18, 2021. Patients presenting with signs and symptoms of external ocular and periocular infections were recruited for the study following a consent (and accent for minors). Patients reporting solely for optical correction, or participants on systemic/topical antibiotics or have performed ocular surgery in the last one week were excluded. A purposive sampling approach was used to recruit one hundred and fourteen (114) eligible subjects.

\section{Study variables}

The independent variables for this study were participants' sociodemographic factors; age, sex, ethnicity, religion, facility, socioeconomic; residence, highest level of education, occupation, marital status, health status; smoking habits, alcohol intake, systemic medical conditions and clinical characteristics (eyes affected, site of the eyes affected, risk factors, patient presenting symptoms) whereas the outcome/dependent variable was prevalence of bacteria ocular and periocular infections. Participants were assessed and clinical presentations classified based on operational terms reported previously ${ }^{7}$, and antimicrobial treatments documented accordingly.

\section{Operational definitions}

Blepharitis in the study was characterized by gritty itchy sore eyes, with crusting and/or collarattes around the base of the eyelashes coupled with clogging of the Meibomian gland, loss of eyelashes and with demodex conjunctivitis. Conjunctivitis was defined as conjunctival lesion delineated by hyperemia, chemosis, whitish tint purulent discharge and hemorrhage. Blepharoconjuntivitis presented as redness of the eye, with dry scaly eyelids and ensuing symptoms of itchiness and burning sensation. In keratoconjuntivitis, cornea and conjunctiva were implicated with complaints of dryness, itching and mucous discharge. Keratitis was defined as lesion of the cornea with characteristic cornea edema, cellular infiltration, pain, redness, photophobia and ciliary injection. Hordeolum was defined swelling and tenderness of the eyelid with acute pain, photophobia and mild epiphora. Ophthalmia neonatorum is a neonatal conjunctivitis presented within the first 28 days of life with signs of eyelid edema, erythema and purulent discharge. Preseptal and orbital cellulitis showed similar features of painful swelling and/or tenderness of the eyelid with the later distinguished from the former by decreased vision and pain on eye motility.

\section{Data collection}

\section{Sociodemographic and clinical data}

The patients sociodemographic, socioeconomic, and health status variables were gathered by the principal investigator and a trained research assistant using a pre-tested structured questionnaire. A comprehensive vision assessment including visual acuity, slit lamp biomicroscopy, and ophthalmoscopy was performed by a registered optometrist on all study participants. Subsequently, patient medical history, primary and secondary diagnosis, and antimicrobial therapy prescribed were extracted using a data collection form.

\section{Specimen collection and transport}

Overall, 103 ocular specimens were obtained from the eyes of patients with external ocular and periocular infections following aseptic procedures. With the patient eyes in an upward position of gaze conjunctival specimen were obtained by gently rolling a moistened saline cotton bud over the lower tarsal plate of the eyelids and fornix of the conjunctiva in repeated strokes, thus from nasal to temporal and vice versa. Samples from corneal ulcer and keratitis infections 
were obtained utilizing a modified version of an original protocol described previously ${ }^{8}$. Briefly, using slit-lamp biomicroscopy, and under topical local anesthesia (1-2 drops of $0.5 \%$ fresh proparacaine), edges of the ulcer were firmly scraped ${ }^{8,9,19}$. On the contrary, none of the patients in our study presented with dacrocystitis and/or blepharitis hence a puncture and/or aspiration of the lacrimal sac as well as swabbing on the eyelids were not undertaken. The swabs were subsequently kept in a sterile freshly prepared nutrient broth and transported from the study site to the Microbiology Laboratory of the Faculty of Pharmacy and Pharmaceutical Sciences, Kwame Nkrumah University of Science and Technology for further microbial investigation.

\section{Laboratory methods}

\section{Culture and identification of bacteria pathogens}

All specimen obtained were initially inoculated on a Nutrient agar and incubated at $37^{\circ} \mathrm{C}$ for 24 hours and plates examined for growth afterwards. Plates with microbial growth were transferred onto various differential and selective media for preliminary isolation and identification. Specifically, bacteria were cultured on a Mannitol Agar, MacConkey Agar, Bismuth sulphite (all from Oxoid Ltd. Basingstoke, Hants United Kingdom brand), Cetrimide agar (HiMedia Laboratories Pvt. Ltd Mumbai, India), $5 \%$ sheep Blood and Chocolate agars and incubated for 24 hours. Of note, with the exception of $5 \%$ blood and chocolate agars which were kept under anaerobic conditions, an aerobic atmosphere was maintained for all other differential agar media used. Conversely plates with no growth were re-incubated for additional 48 hours and consequently counted negative if no growth pattern appeared. In addition, microbial growth on differential media was again sub-cultured on a nutrient agar to obtained pure colonies and subsequently subjected to further phenotypic identification specifically colony morphology, Gram stain, colony morphology and biochemical analyses. Gram-positive bacteria isolates were characterized using coagulase, catalase and bacitracin tests, whereas Gram-negative bacteria were differentiated using citrate utilization, lysine decarboxylase agar, indole and urease tests as well as triple sugar iron agar ${ }^{31,58,59}$. Details of the methodology are summarized in Figure 1.

\section{Quality assurance and control}

The questionnaires employed to gather the sociodemographic and clinical data were pretested at the Anglican Eye Hospital and revised accordingly following their feedback. Questionnaires were written in English and administered by the principal investigator and a trained research assistant. On the one hand, questionnaire was explained in local dialect for study subjects who could not comprehend instructions in English language. The data from study was doubled checked for accuracy and completeness. At the facility, all test tubes with ocular samples were well-labeled to avoid any mismatched. The laboratory reagents and culture media for the experiments were checked for expiry dates, and sterility control performed to ascertain the integrity of the media such as free from contamination. The media performance and/or functionality assessment was conducted using the American Type Culture Collection (ATCC) Standard Reference Strains. Specifically, Escherichia. coli ATCC 25922; Pseudomonas aeruginosa ATCC 4853; Staphylococcus aureus ATCC 25923.

\section{Data protection and management}

The hardcopy version of the filled questionnaires was kept under lock and key and accessible only to the principal investigator and research advisor. Similarly, the softcopy of the non-aggregated dataset was protected using an alphanumeric stringed password. The research report presented to the respective facilities and for publication purposes were aggregated hence individual study participants could not be traced.

\section{Ethical Consideration}

To undertake this study a hierarchical ethical consideration protocols were followed. A written permission was sought from the authorities of the Anglican Eye Clinic, St. Michaels Hospital, and Kumasi South Hospital. The study protocol was then approved by the Committee on Human Research, Publication and Ethics (CHRPE), of the Kwame Nkrumah University of Science and Technology and the Komfo Anokye Teaching Hospital (Reference number: CHRPE/AP/282/21). Written informed consent was obtained from adult participants and for minors a written informed consent was taken from caregivers after study protocol was fully explained to the best of their comprehension. The study adhered to the tenets of the declaration of Helsinki ${ }^{60}$, and all laboratory procedures performed in accordance to the Clinical Laboratory Standard Institute guidelines, CLSI ${ }^{61}$.

\section{Statistical analysis}

Data was entered and managed in Microsoft Excel and further exported into Statistical Package and Service Solution version (IBM Corporation IBM $\AA^{8}$ SPSS $\circledast$ Statistics for Windows, version 25.0 Armonk, NY) compatible with windows. Normality assessment was performed using the Kolmogorov Smirnov statistic. The demographics, socioeconomics, health status and clinical characteristics of the sample were presented and difference between males and females tested with chi-square analysis. Clinical diagnosis, cultural status and antimicrobial treatments were presented in cross tabulations using frequencies and percentages. Association between sample characteristics and prevalence of bacterial infections were investigated using bivariate logistic regression at a significance set at $p<0.05$.

\section{Abbreviations}

AEH: Anglican Eye Hospital, AMR: Antimicrobial Resistance, ARMOR: Antibiotic Resistance Monitoring in Ocular Microorganisms, CHAG: Christian Health Association of Ghana, CHRPE: Committee on Human Research Publication and Ethics, CIP: Ciprofloxacin, CLSI: Clinical Laboratory Standard Institute Guidelines, CONS: Coagulase Negative Staphylococci Species, COR: Crude Odds Ratio, DNA: Deoxyribonucleic acid, FX, Flucoxacillin, KSH: Kumasi South Hospital, GTM: Gentamycin, MDR: Multi Drug Resistance, RFR: Referral, PoB: Polymyxin B, NM: Neomycin; TBM: Tobramycin; TX, tetracycline, OXT: Oxytetracycline, OFC: Ofloxacin; RNA: Ribonucleic acid, SMH: St Michaels Hospital

\section{Declarations}




\section{Acknowledgements}

We acknowledge the authorities and staff of the Anglican Eye Hospital, St Michaels Hospital, and Kumasi South Hospital for their permission and cooperation throughout the study, and thank the study participants or their willfully participation. Again, we appreciate the support of Faculty of Pharmacy and Pharmaceutical Sciences and Department of Chemistry all at KNUST for the use of their facility for the study. Also, we extend our gratitude to Peter Ofori Asumadu (Road Engineer, ECOWAS Abidjan - Lagos Corridor Highway Development Project), Kwadwo Ampadu Boateng (Michigan Technological University, USA), Kwasi Yeboah Kankam (SCP Data Analyst, AstraZeneca, USA), and Dr. Micheal Konney Laryea (Department of Chemistry, KNUST) for their technical support towards the project.

\section{Authors' contribution}

I.O.D.J: Conceptualization; Experimental design; Data curation; Visualization; Methodology; Investigation, Software, Formal analysis; Writing original draft; Writing - review and editing. T.M.P; Project administration; Resources; Supervision, Writing- reviews and editing. L.S.B; Project administration; Resources; Conceptualization; Methodology; Supervision; Writing original draft, writing - review and editing. K.A; Project administration; Resources; writing - review and editing. F.K.D.A; Project administration; Resources; Methodology; writing - review and editing. D.B.K; Resources; Writing review and editing, L.A.O; Resources; Writing - review and editing. A.D.A; Resources; Writing - review and editing. B.O.P; Methodology; Resources; Writing review and editing. S.Y.G; Resources; Writing - review and editing. J.M; Resources; Writing - review and editing. C.A.D; Resources; Writing - review and editing. K.O.A; Methodology; Data curation; Resources; Writing original draft; Writing reviews and editing. All authors have read and approved the manuscript.

\section{Funding}

The study received no specific funding from public, private and/or non-profit organization.

\section{Availability of data materials}

All relevant data and materials supporting the conclusion of this article is/are available within the manuscript and its supporting information files.

\section{Ethical Consideration}

To undertake this study a hierarchical ethical consideration protocols were followed. A written permission was sought from the authorities of the Anglican Eye Clinic, St. Michaels Hospital, and Kumasi South Hospital. The study protocol was then approved by the Committee on Human Research, Publication and Ethics (CHRPE), of the Kwame Nkrumah University of Science and Technology and the Komfo Anokye Teaching Hospital (Reference number: CHRPE/AP/282/21). Written informed consent was obtained from adult participants and for minors a written informed consent was taken from caregivers after study protocol was fully explained to the best of their comprehension. The study adhered to the tenets of the declaration of Helsinki ${ }^{60}$, and all laboratory procedures performed in accordance to the Clinical Laboratory Standard Institute guidelines, $\mathrm{CLSI}{ }^{61}$.

\section{Consent for publication}

Not applicable

\section{Competing interests}

All authors declare no competing interests.

\section{References}

1. Prakash, M. V., Sivakumar, S., Dayal, A., Chitra, A. \& Subramaniam, S. Ocular morbidity patterns among children in schools for the blind in Chennai. Indian J Ophthalmol 65, 733-737, doi:10.4103/ijo.IJO_294_17 (2017).

2. Belyhun, Y. et al. Ocular bacterial infections and antibiotic resistance patterns in patients attending Gondar Teaching Hospital, Northwest Ethiopia. BMC Res Notes 11, 597, doi:10.1186/s13104-018-3705-y (2018).

3. Boadi-Kusi, S. B. et al. A study of Ophthalmia Neonatorum in the Central Reion of Ghana: Causative Agents and Antibiotic Susceptibility Patterns. Glob Pediatr Health 8, 2333794X211019700, doi:10.1177/2333794X211019700 (2021).

4. Mshangila, B. et al. External ocular surface bacterial isolates and their antimicrobial susceptibility patterns among pre-operative cataract patients at Mulago National Hospital in Kampala, Uganda. BMC Ophthalmol 13, 71, doi:10.1186/1471-2415-13-71 (2013).

5. Ayehubizu, Z., Mulu, W. \& Biadglegne, F. Common bacterial causes of external ocular infections, associated risk factors and antibiotic resistance among patients at ophthalmology unit of Felege Hiwot Referral Hospital, Northwest Ethiopia: a cross-sectional study. J Ophthalmic Inflamm Infect 11, 7, doi:10.1186/s12348-021-00238-2 (2021)

6. Diriba, K., Kassa, T., Alemu, Y. \& Bekele, S. In Vitro Biofilm Formation and Antibiotic Susceptibility Patterns of Bacteria from Suspected External Eye Infected Patients Attending Ophthalmology Clinic, Southwest Ethiopia. Int J Microbio/ 2020, 8472395, doi:10.1155/2020/8472395 (2020).

7. Mohammed, A. A., Ali, M. M. \& Zenebe, M. H. Bacterial etiology of ocular and periocular infections, antimicrobial susceptibility profile and associated factors among patients attending eye unit of Shashemene comprehensive specialized hospital, Shashemene, Ethiopia. BMC Ophthalmol 20, 124, doi:10.1186/s12886-020-01398-w (2020). 
8. Getahun, E., Gelaw, B., Assefa, A., Assefa, Y. \& Amsalu, A. Bacterial pathogens associated with external ocular infections alongside eminent proportion of multidrug resistant isolates at the University of Gondar Hospital, northwest Ethiopia. BMC Ophthalmol 17, 151, doi:10.1186/s12886-017-0548-6 (2017).

9. Teweldemedhin, M., Saravanan, M., Gebreyesus, A. \& Gebreegziabiher, D. Ocular bacterial infections at Quiha Ophthalmic Hospital, Northern Ethiopia: an evaluation according to the risk factors and the antimicrobial susceptibility of bacterial isolates. BMC Infect Dis 17, 207, doi:10.1186/s12879-017-2304-1 (2017).

10. Assefa, Y. et al. Bacteriological profile and drug susceptibility patterns in dacryocystitis patients attending Gondar University Teaching Hospital, Northwest Ethiopia. BMC Ophthalmol 15, 34, doi:10.1186/s12886-015-0016-0 (2015).

11. Shiferaw, B., Gelaw, B., Assefa, A., Assefa, Y. \& Addis, Z. Bacterial isolates and their antimicrobial susceptibility pattern among patients with external ocular infections at Borumeda hospital, Northeast Ethiopia. BMC Ophthalmol 15, 103, doi:10.1186/s12886-015-0078-z (2015).

12. Muluye, D., Wondimeneh, Y., Moges, F., Nega, T. \& Ferede, G. Types and drug susceptibility patterns of bacterial isolates from eye discharge samples at Gondar University Hospital, Northwest Ethiopia. BMC Res Notes 7, 292, doi:10.1186/1756-0500-7-292 (2014).

13. Ke, R. et al. Bacteriological profiles and drug susceptibility of Streptococcus isolated from conjunctival sac of healthy children. BMC Pediatr 20, 306 , doi:10.1186/s12887-020-02203-9 (2020).

14. Cho, C. H. \& Lee, S. B. Comparison of clinical characteristics and antibiotic susceptibility between Pseudomonas aeruginosa and P. putida keratitis at a tertiary referral center: a retrospective study. BMC Ophthalmol 18, 204, doi:10.1186/s12886-018-0882-3 (2018).

15. Suwal, S., Bhandari, D., Thapa, P., Shrestha, M. K. \& Amatya, J. Microbiological profile of corneal ulcer cases diagnosed in a tertiary care ophthalmological institute in Nepal. BMC Ophthalmol 16, 209, doi:10.1186/s12886-016-0388-9 (2016).

16. Al-Dhaheri, H. S., Al-Tamimi, M. D., Khandekar, R. B., Khan, M. \& Stone, D. U. Ocular Pathogens and Antibiotic Sensitivity in Bacterial Keratitis Isolates at King Khaled Eye Specialist Hospital, 2011 to 2014. Cornea 35, 789-794, doi:10.1097/ICO.0000000000000844 (2016).

17. Wang, N. et al. Bacterial Spectrum and Antibiotic Resistance Patterns of Ocular Infection: Differences between External and Intraocular Diseases. $J$ Ophthalmol 2015, 813979, doi:10.1155/2015/813979 (2015).

18. Long, C. et al. Causative organisms of post-traumatic endophthalmitis: a 20-year retrospective study. BMC Ophthalmol 14, 34, doi:10.1186/1471-2415-1434 (2014).

19. Bharathi, M. J., Ramakrishnan, R., Shivakumar, C., Meenakshi, R. \& Lionalraj, D. Etiology and antibacterial susceptibility pattern of community-acquired bacterial ocular infections in a tertiary eye care hospital in south India. Indian J Ophthalmol 58, 497-507, doi:10.4103/0301-4738.71678 (2010).

20. Khosravi, A. D., Mehdinejad, M. \& Heidari, M. Bacteriological findings in patients with ocular infection and antibiotic susceptibility patterns of isolated pathogens. Singapore Med J 48, 741-743 (2007).

21. Cabrera-Aguas, M., Khoo, P., George, C. R. R., Lahra, M. M. \& Watson, S. L. Antimicrobial resistance trends in bacterial keratitis over 5 years in Sydney, Australia. Clin Exp Ophthalmol 48, 183-191, doi:10.1111/ceo.13672 (2020).

22. Ly, C. N. et al. Bacteria commonly isolated from keratitis specimens retain antibiotic susceptibility to fluoroquinolones and gentamicin plus cephalothin. Clin Exp Ophthalmol 34, 44-50, doi:10.1111/j.1442-9071.2006.01143.x (2006).

23. Lee, A. E., Niruttan, K., Rawson, T. M. \& Moore, L. S. P. Antibacterial resistance in ophthalmic infections: a multi-centre analysis across UK care settings. BMC Infect Dis 19, 768, doi:10.1186/s12879-019-4418-0 (2019).

24. Grandi, G. et al. Bacterial etiology and antimicrobial resistance trends in ocular infections: A 30-year study, Turin area, Italy. Eur J Ophthalmol 31, 405414, doi:10.1177/1120672119896419 (2021).

25. Papa, V., Blanco, A. R. \& Santocono, M. Ocular flora and their antibiotic susceptibility in patients having cataract surgery in Italy. J Cataract Refract Surg 42, 1312-1317, doi:10.1016/j.jcrs.2016.07.022 (2016).

26. Ta, C. N. et al. Antibiotic resistance patterns of ocular bacterial flora: a prospective study of patients undergoing anterior segment surgery. Ophthalmology 110, 1946-1951, doi:10.1016/s0161-6420(03)00735-8 (2003).

27. Teweldemedhin, M., Gebreyesus, H., Atsbaha, A. H., Asgedom, S. W. \& Saravanan, M. Bacterial profile of ocular infections: a systematic review. BMC Ophthalmol 17, 212, doi:10.1186/s12886-017-0612-2 (2017).

28. Kowalski, R. P. et al. The Prevalence of Bacteria, Fungi, Viruses, and Acanthamoeba From 3,004 Cases of Keratitis, Endophthalmitis, and Conjunctivitis. Eye Contact Lens 46, 265-268, doi:10.1097/ICL.0000000000000642 (2020).

29. Song, X., Xu, L., Sun, S., Zhao, J. \& Xie, L. Pediatric microbial keratitis: a tertiary hospital study. Eur J Ophthalmol 22, 136-141, doi:10.5301/EJO.2011.8338 (2012).

30. Bertino, J. S., Jr. Impact of antibiotic resistance in the management of ocular infections: the role of current and future antibiotics. Clin Ophthalmol 3, 507521, doi:10.2147/opth.s5778 (2009).

31. Sharma, S. Diagnosis of infectious diseases of the eye. Eye (Lond) 26, 177-184, doi:10.1038/eye.2011.275 (2012).

32. Austin, A. et al. Empirical treatment of bacterial keratitis: an international survey of corneal specialists. BMJ Open Ophthalmol 2, doi:10.1136/bmjophth2016-000047 (2017).

33. Machowska, A. \& Stalsby Lundborg, C. Drivers of Irrational Use of Antibiotics in Europe. Int J Environ Res Public Health 16, doi:10.3390/ijerph16010027 (2018).

34. Asbell, P. A. et al. Ocular TRUST: nationwide antimicrobial susceptibility patterns in ocular isolates. Am J Ophthalmol 145, 951-958, doi:10.1016/j.ajo.2008.01.025 (2008).

35. Haas, W., Pillar, C. M., Torres, M., Morris, T. W. \& Sahm, D. F. Monitoring antibiotic resistance in ocular microorganisms: results from the Antibiotic Resistance Monitoring in Ocular micRorganisms (ARMOR) 2009 surveillance study. Am J Ophthalmol 152, 567-574 e563, doi:10.1016/j.ajo.2011.03.010

Page 8/22 
(2011).

36. Metz-Gercek, S. \& Mittermayer, H. The European surveillance activities EARSS and ESAC in the context of ABS International. Wien Klin Wochenschr 120, 264-267, doi:10.1007/s00508-008-0967-8 (2008).

37. Molstad, S. et al. Sustained reduction of antibiotic use and low bacterial resistance: 10-year follow-up of the Swedish Strama programme. Lancet Infect Dis 8, 125-132, doi:10.1016/S1473-3099(08)70017-3 (2008).

38. Yevutsey, S. K. et al. Situational analysis of antibiotic use and resistance in Ghana: policy and regulation. BMC Public Health 17, 896, doi:10.1186/s12889-017-4910-7 (2017).

39. Hawkey, P. M. The growing burden of antimicrobial resistance. J Antimicrob Chemother 62 Suppl 1, i1-9, doi:10.1093/jac/dkn241 (2008).

40. Mainous, A. G., 3rd, Diaz, V. A., Matheson, E. M., Gregorie, S. H. \& Hueston, W. J. Trends in hospitalizations with antibiotic-resistant infections: U.S., 19972006. Public Health Rep 126, 354-360, doi:10.1177/003335491112600309 (2011).

41. Cosgrove, S. E. The relationship between antimicrobial resistance and patient outcomes: mortality, length of hospital stay, and health care costs. Clin Infect Dis 42 Suppl 2, S82-89, doi:10.1086/499406 (2006).

42. Opintan, J. A. et al. Laboratory-based nationwide surveillance of antimicrobial resistance in Ghana. Infect Drug Resist 8, 379-389, doi:10.2147/IDR.S88725 (2015).

43. Ding, P., Li, X., Jia, Z. \& Lu, Z. Multidrug-resistant tuberculosis (MDR-TB) disease burden in China: a systematic review and spatio-temporal analysis. BMC Infect Dis 17, 57, doi:10.1186/s12879-016-2151-5 (2017).

44. Li, B. Y. et al. Rising challenge of multidrug-resistant tuberculosis in China: a predictive study using Markov modeling. Infect Dis Poverty 9,65 , doi:10.1186/s40249-020-00682-7 (2020).

45. Barchitta, M. et al. Antibiotic Consumption and Resistance during a 3-Year Period in Sicily, Southern Italy. Int J Environ Res Public Health 16, doi:10.3390/ijerph16132253 (2019).

46. JL, O. N. Antimicrobial Resistance:Tackling a crisis for the health and wealth of nations. https://amrreview.org/sites/default/files/AMR\%20Review\%20Paper\%20-

\%20Tackling\%20a\%20crisis\%20for\%20the\%20health\%20and\%20wealth\%20of\%20nations_1.pdf. (2014).

47. Mohammed, J., Hounmanou, Y. M. G. \& Thomsen, L. E. Antimicrobial resistance among clinically relevant bacterial isolates in Accra: a retrospective study. BMC Res Notes 11, 254, doi:10.1186/s13104-018-3377-7 (2018).

48. Kyei, S., Appiah, E., Ayerakwa, E. A., Antwi, C. B. \& Asiedu, K. Microbial safety implications of in-use topical diagnostic ophthalmic medications in eye clinics in Ghana. J Optom 12, 263-271, doi:10.1016/j.optom.2019.02.002 (2019).

49. Opintan, J. A. \& Newman, M. J. Prevalence of antimicrobial resistant pathogens from blood cultures: results from a laboratory based nationwide surveillance in Ghana. Antimicrob Resist Infect Control 6, 64, doi:10.1186/s13756-017-0221-0 (2017).

50. Tesfaye, T. et al. Bacterial Profile and Antimicrobial Susceptibility Pattern of External Ocular Infections in Jimma University Specialized Hospital, Southwest Ethiopia. 1, 13-20 (2013).

51. Shahaby AF, AA., A. \& El Tarras, A. Potential Bacterial Pathogens of Red Eye infections and their Antibiotic Susceptibility Patterns in Taif, KSA. https://www.ijcmas.com/vol-4-11/Ahmad\%20F.\%20Shahaby,\%20et\%20al.pdf. Int.J.Curr.Microbiol.App.Sci 11, 383-393, doi:10.2166/wh.2021.274 (2015).

52. Okesola, A. O. \& Salako, A. O. Microbiological profile of bacterial conjunctivitis in ibadan, Nigeria. Ann lb Postgrad Med 8, 20-24, doi:10.4314/aipm.v8i1.63953 (2010).

53. Trimble, M. J., Mlynarcik, P., Kolar, M. \& Hancock, R. E. Polymyxin: Alternative Mechanisms of Action and Resistance. Cold Spring Harb Perspect Med 6, doi:10.1101/cshperspect.a025288 (2016).

54. Jana, S. \& Deb, J. K. Molecular understanding of aminoglycoside action and resistance. Appl Microbiol Biotechnol 70, 140-150, doi:10.1007/s00253-0050279-0 (2006).

55. Mingeot-Leclercq, M. P., Glupczynski, Y. \& Tulkens, P. M. Aminoglycosides: activity and resistance. Antimicrob Agents Chemother 43, 727-737, doi:10.1128/AAC.43.4.727 (1999).

56. Campoli-Richards, D. M. et al. Ciprofloxacin. A review of its antibacterial activity, pharmacokinetic properties and therapeutic use. Drugs $35,373-447$, doi:10.2165/00003495-198835040-00003 (1988).

57. Nash, S. D. et al. Ocular Chlamydia trachomatis Infection Under the Surgery, Antibiotics, Facial Cleanliness, and Environmental Improvement Strategy in Amhara, Ethiopia, 2011-2015. Clin Infect Dis 67, 1840-1846, doi:10.1093/cid/ciy377 (2018).

58. Hemavathi, Sarmah, P. \& Shenoy, P. Profile of microbial isolates in ophthalmic infections and antibiotic susceptibility of the bacterial isolates: a study in an eye care hospital, bangalore. J Clin Diagn Res 8, 23-25, doi:10.7860/JCDR/2014/6852.3910 (2014).

59. Hesje, C. K., Sanfilippo, C. M., Haas, W. \& Morris, T. W. Molecular epidemiology of methicillin-resistant and methicillin-susceptible Staphylococcus aureus isolated from the eye. Curr Eye Res 36, 94-102, doi:10.3109/02713683.2010.534229 (2011).

60. Association, W. M. Declaration of Helsinki - ethical principles for medical research involving human subjects. (2013).

61. Institute, C. a. L. S. Performance Standards for Antimicrobial Susceptibility Testing; Twenty-Seven Informational Supplement; CLSI Document M02A12and M07-A10,CLSI. (2017).

\section{Tables}


Table 1: Description of the sample

Page 10/22 


\section{Demographic characteristics}

Age group (years)

\begin{tabular}{|c|c|c|c|c|}
\hline $0-2$ & $21.1(24)$ & $20.0(10)$ & $21.9(14)$ & 0.948 \\
\hline 17-Mar & $29.8(34)$ & 32.0 (16) & $28.1(18)$ & \\
\hline $18-39$ & 27.2 (31) & 28.0 (14) & $26.6(17)$ & \\
\hline \multicolumn{5}{|l|}{ Ethnicity ${ }^{\ddagger}$} \\
\hline Northerner & $7.0(8)$ & $10.0(5)$ & $4.7(3)$ & \\
\hline \multicolumn{5}{|l|}{ Religion } \\
\hline Catholic & $13.2(15)$ & $22.0(11)$ & $6.3(4)$ & 0.041 \\
\hline Protestant & 80.7 (92) & $76 . .0$ (38) & $84.4(54)$ & \\
\hline
\end{tabular}

\section{Socioeconomic characteristics}

Residence

Rura

$59.6(68)$

$60.0(30)$

$59.4(38)$

0.946

Urban

$40.4(46)$

$40.0(20)$

$40.6(26)$

Highest level of education

None

$4.4(5)$

4.0 (2)

4.8 (3)

0.943

Preschool

13.3 (15)

$12.0(6)$

14.3 (9)

Primary

$33.6(38)$

30.0 (15)

$36.5(23)$

Secondary

29.2 (33)

32.0 (16)

$27.0(17)$

Tertiary

8.0 (9)

10.0 (5)

6.3 (4)

Not applicable*

11.5 (13)

$12.0(6)$

11.1 (7)

Occupation

Farming

$4.4(5)$

6.0 (3)

3.1 (2)

0.092

Wage/Salary worker

7.0 (8)

Construction worker

2.6 (3)

$6.0(3)$

$7.8(5)$

Dressmaking

1.8 (2)

6.0 (3)

$0.0(0)$

Driver/Transport business

$2.6(3)$

Businessman/woman

$5.3(6)$

$0.0(0)$

3.1 (2)

Welding

$1.8(2)$

Trading

$8.8(10)$

Beautician

$1.8(2)$

6.0 (3)

$0.0(0)$

Hairdressing

2.6 (3)

Student

$43.9(50)$

4.0 (2)

$6.3(4)$

4.0 (2)

$0.0(0)$

Unemployed

$5.3(6)$

12.3 (14)

$4.0(2)$

12.5 (8)

Not applicable*

$0.0(0)$

3.1 (2)

2.0 (1)

3.1 (2)

46.0 (23)

42.2 (27)

Marital status

2.0 (1)

7.8 (5)

14.0 (7)

$10.9(7)$

Not applicable* 


\begin{tabular}{llll}
\hline Single & $21.2(24)$ & $24.0(12)$ & $19.0(12)$ \\
\hline Married & $21.2(24)$ & $18.0(9)$ & $23.8(15)$ \\
\hline Cohabiting & $3.5(4)$ & $4.0(2)$ & $3.2(2)$ \\
\hline Divorced & $2.7(3)$ & $2.0(1)$ & $3.2(2)$ \\
\hline Separated & $0.9(1)$ & $0.0(0)$ & $1.6(1)$ \\
\hline Widow & $1.8(2)$ & $2.0(1)$ & $1.6(1)$
\end{tabular}

\section{Health status variables}

Smoking habits

Not applicable*

Never smoked

Past smoker

$44.7(51)$

46.0 (23)

43.8 (28)

0.237

$52.6(60)$

$48.0(24)$

56.3 (36)

Current smoker

$1.8(2)$

4.0 (2)

$0.0(0)$

Alcohol intake habits

Not applicable*

$0.9(1)$

$2.0(1)$

$0.0(0)$

I never drink

43.9 (50)

$42.0(21)$

45.3 (29)

0.054

I drink only on special occasions

$46.5(53)$

40.0 (20)

$51.6(33)$

I drink once or twice a week

7.9 (9)

$14.0(7)$

$3.1(2)$

$1.8(2)$

$4.0(2)$

$0.0(0)$

Average alcohol consumption per week

None

1 unit

90.4 (103)

$82.0(41)$

$96.9(62)$

0.027

2-5 unit

$6.1(7)$

$12.0(6)$

$1.6(1)$

$3.5(4)$

6.0 (3)

$1.6(1)$

Medical history

Diabetes

$4.4(5)$

$6.1(7)$

$0.9(1)$

Tuberculosis

Sexually transmitted diseases

0.9 (1)

4.4 (5)

Peptic ulcer

Others

$2.6(3)$

Is condition ongoing

Not applicable*

No

Yes

Are you currently taking any medication

No
Yes

$82.5(94)$

$17.5(20)$

$80.7(92)$

$2.6(3)$

$16.7(19)$

$2.0(1)$

$6.3(4)$

0.272

Class of medications

Antibiotic

Antidiabetic

Antihypertensive

Antimalarial

Anticholesterol

Others

$3.5(4)$
$3.5(4)$
$5.3(6)$
$0.9(1)$
$0.9(1)$
$7.9(9)$

*, Under age; \%, percentage frequency; ${ }^{{ }^{*}}$ northerner is a collective name for all ethnic group in the northern region of Ghana 
Table 2: Clinical characteristics of external ocular and periocular infections among a Ghanaian ophthalmic population

Page $13 / 22$ 
Total $(\mathrm{N}=114) \quad$ Males $(\mathrm{N}=50,43.9 \%) \quad$ Females $(\mathrm{N}=64,56.1 \%)$

$\%$ (frequency) \% (frequency) $\quad$ (frequency) $\quad p$-value for linearity

Eyes affected

\begin{tabular}{|c|c|c|c|c|}
\hline Right eye; oculus dexter & $16.7(19)$ & $22.0(11)$ & $12.5(8)$ & 0.369 \\
\hline Left eye; oculus sinister & $16.7(19)$ & $14.0(7)$ & $18.8(12)$ & \\
\hline Both eyes; oculus uterque & $66.7(76)$ & $64.0(32)$ & $68.8(44)$ & \\
\hline \multicolumn{5}{|l|}{ Site of eye affected } \\
\hline Eyelid/eye lashes & $20.2(23)$ & $22.0(11)$ & $18.8(12)$ & 0.668 \\
\hline Conjunctiva & $94.7(108)$ & $92.0(46)$ & $96.9(62)$ & 0.247 \\
\hline Cornea & $18.4(21)$ & $26.0(13)$ & $12.5(8)$ & 0.065 \\
\hline \multicolumn{5}{|l|}{ Risk factors } \\
\hline Previous eye infections & $45.1(51)$ & $44.0(22)$ & $46.0(29)$ & 0.829 \\
\hline Previous use of antimicrobials & $55.8(63)$ & $52.0(26)$ & $58.7(37)$ & 0.474 \\
\hline Previous usage of contact lenses & $0.9(1)$ & $0.0(0)$ & $1.6(1)$ & 0.371 \\
\hline Previous use of spectacles & $9.7(11)$ & $10.0(5)$ & $9.5(6)$ & 0.932 \\
\hline Previous ocular trauma & $20.4(23)$ & $30.0(15)$ & $12.7(8)$ & 0.023 \\
\hline Previous ocular surgery & $2.7(3)$ & $2.0(1)$ & $3.2(2)$ & 0.700 \\
\hline \multicolumn{5}{|l|}{ Duration of illness } \\
\hline$<1$ week & $63.7(72)$ & $66.0(33)$ & $61.9(39)$ & 0.649 \\
\hline 2 - 4 weeks & $18.6(21)$ & $20.0(10)$ & $17.5(11)$ & \\
\hline$>4$ weeks & $17.7(20)$ & $14.0(7)$ & $20.6(13)$ & \\
\hline Previous application of mascara & $6.2(7)$ & $0.0(0)$ & $11.1(7)$ & 0.015 \\
\hline Previous application of breastmilk & $2.7(3)$ & $2.0(1)$ & $3.2(2)$ & 0.700 \\
\hline \multicolumn{5}{|l|}{ Presenting visual acuity } \\
\hline \multicolumn{5}{|l|}{ Right eye; oculus dexter } \\
\hline Unavailable & $2.6(3)$ & $2.0(1)$ & $3.1(2)$ & 0.939 \\
\hline FFL & $23.7(27)$ & $24.0(12)$ & $23.4(15)$ & \\
\hline $6 / 5-6 / 18$ & $63.2(72)$ & $62.0(31)$ & $64.1(41)$ & \\
\hline $6 / 24-6 / 60$ & $7.9(9)$ & $8.0(4)$ & $7.8(5)$ & \\
\hline $3 / 60-1 / 60$ & $2.6(3)$ & $4.0(2)$ & $1.6(1)$ & \\
\hline \multicolumn{5}{|l|}{ Left eye; oculus dexter } \\
\hline Unavailable & $2.6(3)$ & $2.0(1)$ & $3.1(2)$ & 0.356 \\
\hline FFL & $23.7(27)$ & $24.0(12)$ & $23.4(15)$ & \\
\hline $6 / 5-6 / 18$ & $67.5(77)$ & $66.0(33)$ & $68.8(44)$ & \\
\hline $6 / 24-6 / 60$ & $1.8(2)$ & $0.0(0)$ & $3.1(2)$ & \\
\hline $3 / 60-1 / 60$ & $4.4(5)$ & $8.0(4)$ & $1.6(1)$ & \\
\hline \multicolumn{5}{|l|}{ Both eyes; oculus uterque } \\
\hline Unavailable & $91.2(104)$ & $86.0(43)$ & $95.3(61)$ & 0.266 \\
\hline FFL & $0.9(1)$ & $2.0(1)$ & $0.0(0)$ & \\
\hline $6 / 5-6 / 18$ & $7.0(8)$ & $10.0(5)$ & $4.7(3)$ & \\
\hline $3 / 60-1 / 60$ & $0.9(1)$ & $2.0(1)$ & $0.0(0)$ & \\
\hline \multicolumn{5}{|l|}{ Presenting patient symptoms } \\
\hline Eye pain & $50.9(58)$ & $42.0(21)$ & $57.8(37)$ & 0.094 \\
\hline Itching & $60.5(69)$ & $54.0(27)$ & $65.6(42)$ & 0.208 \\
\hline
\end{tabular}




\begin{tabular}{|c|c|c|c|c|}
\hline Falling lashes & $0.9(1)$ & $0.0(0)$ & $1.6(1)$ & 0.375 \\
\hline Lacrimation/watering & $61.4(70)$ & $64.0(32)$ & $59.4(38)$ & 0.615 \\
\hline Hyperemia/redness & $69.3(79)$ & $72.0(36)$ & $67.2(43)$ & 0.580 \\
\hline Swelling & $21.9(25)$ & $22.0(11)$ & $21.9(14)$ & 0.987 \\
\hline Discharge & $62.3(71)$ & $70.0(35)$ & $56.3(33)$ & 0.133 \\
\hline Burning sensation & $7.9(9)$ & $6.0(3)$ & $9.4(6)$ & 0.507 \\
\hline Foreign body sensation & $10.5(12)$ & $14.0(7)$ & $7.8(5)$ & 0.285 \\
\hline Others & $11.4(13)$ & $4.0(2)$ & $17.2(11)$ & 0.028 \\
\hline \multicolumn{5}{|l|}{ Test/investigations } \\
\hline Visual acuity & $99.1(113)$ & $98.0(49)$ & $100(64)$ & 0.256 \\
\hline Slit lamp Biomicroscopy & $99.1(113)$ & $98.0(49)$ & $100(64)$ & 0.256 \\
\hline Ophthalmoscopy & $98.2(112)$ & $98.0(49)$ & $98.4(63)$ & 0.860 \\
\hline Microbial analysis & $90.4(103)$ & $88.0(44)$ & $92.2(59)$ & 0.452 \\
\hline \multicolumn{5}{|l|}{ Clinical signs } \\
\hline \multicolumn{5}{|l|}{ Eyelashes } \\
\hline Healthy & $98.2(112)$ & $100.0(50)$ & $96.9(62)$ & 0.451 \\
\hline Misdirected & $0.9(1)$ & $0.0(0)$ & $1.6(1)$ & \\
\hline Crust formation & $0.9(1)$ & $0.0(0)$ & $1.6(1)$ & \\
\hline \multicolumn{5}{|l|}{ Eyelids } \\
\hline Healthy & $66.7(76)$ & $66.0(33)$ & $67.2(43)$ & 0.819 \\
\hline Papillae & $17.5(20)$ & $18.0(9)$ & $17.2(11)$ & \\
\hline Cobblestones & $1.8(2)$ & $2.0(1)$ & $1.6(1)$ & \\
\hline Swelling & $11.4(13)$ & $12.0(6)$ & $10.9(7)$ & \\
\hline Crust & $0.9(1)$ & $2.0(1)$ & $0.0(0)$ & \\
\hline Drooping & $0.9(1)$ & $0.0(0)$ & $1.6(1)$ & \\
\hline Rashes & $0.9(1)$ & $0.0(0)$ & $1.6(1)$ & \\
\hline \multicolumn{5}{|l|}{ Conjunctiva } \\
\hline Healthy & $26.3(30)$ & $28.0(14)$ & $25.0(16)$ & 0.646 \\
\hline Injection & $71.9(82)$ & $72.0(36)$ & $71.9(46)$ & \\
\hline Limbal papillae & $0.9(1)$ & $0.0(0)$ & $1.6(1)$ & \\
\hline Limbal pigmentation & $0.9(1)$ & $0.0(0)$ & $1.6(1)$ & \\
\hline \multicolumn{5}{|l|}{ Cornea } \\
\hline Transparent & $87.7(100)$ & $78.0(39)$ & $95.3(61)$ & 0.045 \\
\hline Opacities & $3.5(4)$ & $4.0(2)$ & $3.1(2)$ & \\
\hline Laceration & $0.9(1)$ & $2.0(1)$ & $0.0(0)$ & \\
\hline Abrasions & $7.0(8)$ & $14.0(7)$ & $1.6(1)$ & \\
\hline Ulcer & $0.9(1)$ & $2.0(1)$ & $0.0(0)$ & \\
\hline \multicolumn{5}{|l|}{ Sclera } \\
\hline Healthy & $83.3(95)$ & $78.0(39)$ & $87.5(56)$ & 0.177 \\
\hline Pigmented & $16.7(19)$ & $22.0(11)$ & $12.5(8)$ & \\
\hline \multicolumn{5}{|l|}{ Anterior chamber } \\
\hline Deep & $98.2(112)$ & $96.0(48)$ & $100(64)$ & 0.106 \\
\hline Shallow & $1.8(2)$ & $4.0(2)$ & $0.0(0)$ & \\
\hline
\end{tabular}




\begin{tabular}{|c|c|c|c|c|}
\hline Healthy (PERLLA) & $99.1(113)$ & $98.0(49)$ & $100.0(64)$ & 0.256 \\
\hline Abnormal (RAPD) & $0.9(1)$ & $2.0(1)$ & $0.0(0)$ & \\
\hline \multicolumn{5}{|l|}{ Iris } \\
\hline Health (Dark and flat) & $99.1(113)$ & $98.0(49)$ & $100.0(64)$ & 0.256 \\
\hline Prolapse & $0.9(1)$ & $2.0(1)$ & $0.0(0)$ & \\
\hline \multicolumn{5}{|l|}{ Lens } \\
\hline Transparent & $94.7(108)$ & $92.0(46)$ & $96.9(62)$ & 0.247 \\
\hline Opacities & $5.3(6)$ & $8.0(4)$ & $3.1(2)$ & \\
\hline \multicolumn{5}{|c|}{ Number of antibiotics administered } \\
\hline None & $7.9(9)$ & $6.0(3)$ & $9.4(6)$ & 0.351 \\
\hline 1 & $33.3(38)$ & $38.0(19)$ & $29.7(19)$ & \\
\hline 2 & $40.4(44)$ & $44.0(22)$ & $37.5(24)$ & \\
\hline$\geq 3$ & $18.4(21)$ & $12.0(6)$ & $23.4(15)$ & \\
\hline \multicolumn{5}{|l|}{ Clinical presentation } \\
\hline Conjunctivitis & $60.5(69)$ & $52.0(26)$ & $67.2(43)$ & 0.216 \\
\hline Blepharoconjuntivitis & $9.6(11)$ & $10.0(5)$ & $9.4(6)$ & \\
\hline Keratoconjunctivitis & $11.4(13)$ & $16.0(8)$ & $7.8(5)$ & \\
\hline Ophthalmia neonatorum & $0.9(1)$ & $2.0(1)$ & $0.0(0)$ & \\
\hline Ocular trauma & $6.1(7)$ & $8.0(4)$ & $4.7(3)$ & \\
\hline Preseptal cellulitis & $0.9(1)$ & $0.0(0)$ & $1.6(1)$ & \\
\hline Hordeolum & $2.6(3)$ & $0(0.0)$ & $3(4.7)$ & \\
\hline Keratitis & $7.9(9)$ & $6(12.0)$ & $3(4.7)$ & \\
\hline \multicolumn{5}{|l|}{ Associated conditions } \\
\hline Dry eye syndrome & $10.5(12)$ & $6.0(3)$ & $14.1(9)$ & 0.164 \\
\hline Pterygium & $4.4(5)$ & $4.0(2)$ & $4.7(3)$ & 0.859 \\
\hline Pingueculum & $0.9(1)$ & $0.0(0)$ & $1.6(1)$ & 0.375 \\
\hline Headaches & $5.3(6)$ & $8.0(4)$ & $3.1(2)$ & 0.247 \\
\hline
\end{tabular}

FFL, fixate-and-follow light; PERLLA, pupils are equal, round, and reactive to light and accommodation; RAPD, relative afferent pupillary defect 


\begin{tabular}{|c|c|c|c|c|c|c|c|c|c|c|c|c|}
\hline \multirow[t]{2}{*}{$\begin{array}{l}\text { Types of clinical } \\
\text { presentation }\end{array}$} & \multicolumn{2}{|c|}{$\begin{array}{l}\text { Bacteria culture results } \\
\mathrm{n}(\%)\end{array}$} & \multicolumn{10}{|c|}{ Antimicrobial therapy employed in treating external ocular and periocular infections $n$ (\%) } \\
\hline & Positive & Negative & RFR & CIP & GTM & PoB & NM & TBM & TX & OTX & OFC & $\mathrm{FX}$ \\
\hline Conjunctivitis & $55(94.8)$ & $3(5.2)$ & $\begin{array}{l}0 \\
(0.0)\end{array}$ & $\begin{array}{l}22 \\
(31.9)\end{array}$ & $\begin{array}{l}2 \\
(2.9)\end{array}$ & $\begin{array}{l}29 \\
(42.0)\end{array}$ & $\begin{array}{l}22 \\
(31.9)\end{array}$ & $\begin{array}{l}13 \\
(18.8)\end{array}$ & $\begin{array}{l}16 \\
(23.2)\end{array}$ & $\begin{array}{l}12 \\
(2.6)\end{array}$ & $\begin{array}{l}0 \\
(0.0)\end{array}$ & $0(0.0)$ \\
\hline Blepharoconjuntivitis & $11(100.0)$ & $0(0.0)$ & $\begin{array}{l}0 \\
(0.0)\end{array}$ & $\begin{array}{l}2 \\
(18.2)\end{array}$ & $\begin{array}{l}0 \\
(0.0)\end{array}$ & $\begin{array}{l}8 \\
(72.7)\end{array}$ & $\begin{array}{l}5 \\
(45.5)\end{array}$ & $1(9.1)$ & $\begin{array}{l}2 \\
(18.2)\end{array}$ & $\begin{array}{l}3 \\
(27.3)\end{array}$ & $\begin{array}{l}0 \\
(0.0)\end{array}$ & $0(0.0)$ \\
\hline Keratoconjunctivitis & $12(92.3)$ & $1(7.7)$ & $\begin{array}{l}0 \\
(0.0)\end{array}$ & $\begin{array}{l}2 \\
(15.4)\end{array}$ & $\begin{array}{l}0 \\
(0.0)\end{array}$ & $\begin{array}{l}5 \\
(38.5)\end{array}$ & $\begin{array}{l}9 \\
(69.2)\end{array}$ & $0(0.0)$ & $\begin{array}{l}4 \\
(30.8)\end{array}$ & $0(0.0)$ & $\begin{array}{l}0 \\
(0.0)\end{array}$ & $0(0.0)$ \\
\hline $\begin{array}{l}\text { Ophthalmia } \\
\text { neonatorum }\end{array}$ & $1(100.0)$ & $0(0.0)$ & $\begin{array}{l}0 \\
(0.0)\end{array}$ & $0(0.0)$ & $\begin{array}{l}0 \\
(0.0)\end{array}$ & $\begin{array}{l}1 \\
(100.0)\end{array}$ & $0(0.0)$ & $\begin{array}{l}1 \\
(100.0)\end{array}$ & $0(0.0)$ & $\begin{array}{l}1 \\
(100.0)\end{array}$ & $\begin{array}{l}0 \\
(0.0)\end{array}$ & $0(0.0)$ \\
\hline Ocular trauma & $7(100.0)$ & $0(0.0)$ & $\begin{array}{l}1 \\
(14.3)\end{array}$ & $\begin{array}{l}3 \\
(42.9)\end{array}$ & $\begin{array}{l}0 \\
(0.0)\end{array}$ & $\begin{array}{l}1 \\
(14.3)\end{array}$ & $\begin{array}{l}1 \\
(14.3)\end{array}$ & $0(0.0)$ & $\begin{array}{l}2 \\
(28.6)\end{array}$ & $0(0.0)$ & $\begin{array}{l}0 \\
(0.0)\end{array}$ & $\begin{array}{l}1 \\
(14.3)\end{array}$ \\
\hline Preseptal cellulitis & $1(100.0)$ & $0(0.0)$ & $\begin{array}{l}0 \\
(0.0)\end{array}$ & $0(0.0)$ & $\begin{array}{l}0 \\
(0.0)\end{array}$ & $0(0.0)$ & $\begin{array}{l}1 \\
(100.0)\end{array}$ & $0(0.0)$ & $\begin{array}{l}1 \\
(100.0)\end{array}$ & $0(0.0)$ & $\begin{array}{l}0 \\
(0.0)\end{array}$ & $\begin{array}{l}1 \\
(100.0)\end{array}$ \\
\hline Hordeolum & $3(100.0)$ & $0(0.0)$ & $\begin{array}{l}0 \\
(0.0)\end{array}$ & $\begin{array}{l}1 \\
(33.3)\end{array}$ & $\begin{array}{l}0 \\
(0.0)\end{array}$ & $\begin{array}{l}1 \\
(33.3)\end{array}$ & $\begin{array}{l}1 \\
(33.3)\end{array}$ & $0(0.0)$ & $0(0.0)$ & $0(0.0)$ & $\begin{array}{l}0 \\
(0.0)\end{array}$ & $\begin{array}{l}3 \\
(100.0)\end{array}$ \\
\hline Keratitis & $8(88.9)$ & $1(11.1)$ & $\begin{array}{l}0 \\
(0.0)\end{array}$ & $\begin{array}{l}6 \\
(66.7)\end{array}$ & $\begin{array}{l}1 \\
(11.1)\end{array}$ & $\begin{array}{l}2 \\
(22.2)\end{array}$ & $\begin{array}{l}1 \\
(11.1)\end{array}$ & $\begin{array}{l}1 \\
(11.1)\end{array}$ & $\begin{array}{l}3 \\
(33.3)\end{array}$ & $\begin{array}{l}2 \\
(22.2)\end{array}$ & $\begin{array}{l}1 \\
(11.1)\end{array}$ & $0(0.0)$ \\
\hline Total & $98(95.1)$ & $5(4.4)$ & $\begin{array}{l}1 \\
(0.9)\end{array}$ & $\begin{array}{l}36 \\
(31.6)\end{array}$ & $\begin{array}{l}3 \\
(2.6)\end{array}$ & $\begin{array}{l}47 \\
(41.2)\end{array}$ & $\begin{array}{l}40 \\
(35.1)\end{array}$ & $\begin{array}{l}16 \\
(14.0)\end{array}$ & $\begin{array}{l}28 \\
(24.6)\end{array}$ & $\begin{array}{l}18 \\
(15.8)\end{array}$ & $\begin{array}{l}1 \\
(0.9)\end{array}$ & $5(4.4)$ \\
\hline
\end{tabular}

Table 4

Distribution of bacteria isolates across different clinical presentations of external ocular and periocular infections in a Ghanaian ophthalmic population

\begin{tabular}{|c|c|c|c|c|c|c|c|c|c|}
\hline \multirow{2}{*}{$\begin{array}{l}\text { Bacteria } \\
\text { isolates }\end{array}$} & \multicolumn{9}{|c|}{ Types of clinical presentation } \\
\hline & $\begin{array}{l}\text { Conjunctivitis } \\
\mathrm{n}(\%)\end{array}$ & $\begin{array}{l}\text { Blepharoconjuntivitis } \\
\mathrm{n}(\%)\end{array}$ & $\begin{array}{l}\text { Keratoconjunctivitis } \\
\mathrm{n}(\%)\end{array}$ & $\begin{array}{l}\text { Ophthalmia } \\
\text { neonatorum } \\
\mathrm{n}(\%)\end{array}$ & $\begin{array}{l}\text { Ocular } \\
\text { trauma } \\
\mathrm{n}(\%)\end{array}$ & $\begin{array}{l}\text { Preseptal } \\
\text { cellulitis } \\
\text { n (\%) }\end{array}$ & $\begin{array}{l}\text { Hordeolum } \\
\mathrm{n}(\%)\end{array}$ & $\begin{array}{l}\text { Keratitis } \\
\mathrm{n}(\%)\end{array}$ & $\begin{array}{l}\text { Total } \\
\text { isolates } \\
\mathrm{n}(\%)\end{array}$ \\
\hline \multicolumn{10}{|l|}{ Gram positive } \\
\hline S. aureus & $12(21.8)$ & $8(72.7)$ & $4(33.3)$ & $0(0.0)$ & $\begin{array}{l}1 \\
(14.3)\end{array}$ & $1(100.0)$ & $0(0.0)$ & $1(12.5)$ & $\begin{array}{l}27 \\
(27.6)\end{array}$ \\
\hline CONS & $8(14.5)$ & $2(18.2)$ & $1(8.3)$ & $1(100.0)$ & $\begin{array}{l}1 \\
(14.3)\end{array}$ & $0(0.0)$ & $0(0.0)$ & $0(0.0)$ & $\begin{array}{l}13 \\
(13.3)\end{array}$ \\
\hline $\begin{array}{l}\text { Streptococcus } \\
\text { spp }\end{array}$ & $1(1.8)$ & $0(0.0)$ & $0(0.0)$ & $0(0.0)$ & $0(0.0)$ & $0(0.0)$ & $0(0.0)$ & $0(0.0)$ & $1(1.0)$ \\
\hline \multicolumn{10}{|l|}{$\begin{array}{l}\text { Gram } \\
\text { negative }\end{array}$} \\
\hline $\begin{array}{l}\text { Citrobacter } \\
\text { spp }\end{array}$ & $1(1.8)$ & $0(0.0)$ & $0(0.0)$ & $0(0.0)$ & $\begin{array}{l}1 \\
(14.3)\end{array}$ & $0(0.0)$ & $0(0.0)$ & $0(0.0)$ & $2(2.0)$ \\
\hline Serratia spp & $0(0.0)$ & $0(0.0)$ & $0(0.0)$ & $0(0.0)$ & $0(0.0)$ & $0(0.0)$ & $1(33.3)$ & $0(0.0)$ & $1(1.0)$ \\
\hline $\begin{array}{l}\text { Salmonella } \\
\text { spp }\end{array}$ & $1(1.8)$ & $0(0.0)$ & $1(8.3)$ & $0(0.0)$ & $\begin{array}{l}1 \\
(14.3)\end{array}$ & $0(0.0)$ & $0(0.0)$ & $0(0.0)$ & $3(3.1)$ \\
\hline E. coli & $1(1.8)$ & $0(0.0)$ & $0(0.0)$ & $0(0.0)$ & $0(0.0)$ & $0(0.0)$ & $0(0.0)$ & $0(0.0)$ & $1(1.0)$ \\
\hline $\begin{array}{l}\text { Klebsiella } \\
\text { spp. }\end{array}$ & $0(0.0)$ & $0(0.0)$ & $0(0.0)$ & $0(0.0)$ & $\begin{array}{l}1 \\
(14.3)\end{array}$ & $0(0.0)$ & $0(0.0)$ & $0(0.0)$ & $1(1.0)$ \\
\hline P. aeruginosa & $22(40.0)$ & $1(9.1)$ & $5(41.7)$ & $0(0.0)$ & $\begin{array}{l}2 \\
(28.6)\end{array}$ & $0(0.0)$ & $2(66.7)$ & $6(75.0)$ & $\begin{array}{l}38 \\
(38.8)\end{array}$ \\
\hline P. putida & $9(16.4)$ & $0(0.0)$ & $1(8.3)$ & $0(0.0)$ & $0(0.0)$ & $0(0.0)$ & $0(0.0)$ & $1(12.5)$ & $11(11.2)$ \\
\hline Total & $55(56.1)$ & $11(11.2)$ & $12(12.2)$ & $1(1.0)$ & $7(7.1)$ & $1(1.0)$ & $3(3.1)$ & $8(8.2)$ & $\begin{array}{l}98 \\
(100.0)\end{array}$ \\
\hline
\end{tabular}




\begin{tabular}{|c|c|c|c|}
\hline & OR & $95 \% \mathrm{Cl}$ & $\mathrm{p}$-value \\
\hline \multicolumn{4}{|c|}{ Demographic characteristics } \\
\hline Age (years) & 1.04 & $0.97-1.11$ & 0.237 \\
\hline \multicolumn{4}{|l|}{ Age group (years) } \\
\hline $0-2$ & Ref & & \\
\hline $3-17$ & & & 0.998 \\
\hline $18-39$ & & & 0.999 \\
\hline$\geq 40$ & 1.00 & & 1.000 \\
\hline \multicolumn{4}{|l|}{ Gender } \\
\hline Man & Ref & & \\
\hline Woman & & & 0.998 \\
\hline Not applicable* & & & 0.998 \\
\hline \multicolumn{4}{|c|}{ Sex designated at birth } \\
\hline Male & Ref & & \\
\hline Female & 0.32 & $0.03-2.97$ & 0.316 \\
\hline \multicolumn{4}{|l|}{ Ethnicity } \\
\hline Akan & Ref & & \\
\hline Northerner & & & 0.999 \\
\hline \multicolumn{4}{|l|}{ Religion } \\
\hline Catholic & Ref & & \\
\hline Protestant & & & 0.999 \\
\hline Muslim & 1.00 & & 1.000 \\
\hline Atheist & 1.00 & & 1.000 \\
\hline
\end{tabular}

\section{Socioeconomic characteristics}

Residence

\begin{tabular}{|c|c|c|c|}
\hline Rural & Ref & & \\
\hline Urban & 0.99 & $0.16-6.21$ & 0.993 \\
\hline \multicolumn{4}{|c|}{ Highest level of education } \\
\hline None & Ref & & \\
\hline Preschool & 1.00 & & 1.000 \\
\hline Primary & & & 0.999 \\
\hline Secondary & & & 0.999 \\
\hline Tertiary & 1.00 & & 1.000 \\
\hline Not applicable* & 1.00 & & 1.000 \\
\hline \multicolumn{4}{|l|}{ Occupation } \\
\hline Not applicable* & Ref & & \\
\hline Student & & & 0.999 \\
\hline Trading & 1.00 & & 1.000 \\
\hline Welding & 1.00 & & 1.000 \\
\hline Hairdressing & 1.00 & & 1.000 \\
\hline Unemployed & 1.00 & & 1.000 \\
\hline Construction worker & 1.00 & & 1.000 \\
\hline Beautician & 1.00 & & 1.000 \\
\hline
\end{tabular}




\begin{tabular}{|c|c|c|c|}
\hline Wage or salary worker & 1.00 & & 1.000 \\
\hline Driver/Transport business & 1.00 & & 1.000 \\
\hline Businessman/woman & 1.00 & & 1.000 \\
\hline Farming & 1.00 & & 1.000 \\
\hline Haidressing & 1.00 & & 1.000 \\
\hline \multicolumn{4}{|l|}{ Marital status } \\
\hline Not applicable* & Ref & & \\
\hline Single & 2.24 & $0.24-21.29$ & 0.481 \\
\hline Married & & & 0.998 \\
\hline Cohabiting & & & 0.999 \\
\hline Divorced & & & 0.999 \\
\hline Seperated & & & 1.000 \\
\hline Widow & & & 0.999 \\
\hline \multicolumn{4}{|l|}{ Health status variables } \\
\hline \multicolumn{4}{|l|}{ Smoking habits } \\
\hline Not applicable* & Ref & & \\
\hline Never smoker & 6.27 & $0.67-58.30$ & 0.107 \\
\hline Past smoker & & & 0.999 \\
\hline Current smoker & & & 1.000 \\
\hline \multicolumn{4}{|l|}{ Alcohol intake habits } \\
\hline Not applicable* & Ref & & \\
\hline I never drink & 5.67 & $0.61-52.83$ & 0.128 \\
\hline I drink only on special occasions & & & 0.999 \\
\hline I drink once or twice a week & & & 0.999 \\
\hline \multicolumn{4}{|c|}{ Average alcohol consumption per week } \\
\hline None & Ref & & \\
\hline 1 unit & & & 0.999 \\
\hline 2-5 unit & & & 0.999 \\
\hline \multicolumn{4}{|l|}{ Medical History } \\
\hline \multicolumn{4}{|l|}{ Diabetes } \\
\hline No & Ref & & \\
\hline Yes & & & 0.999 \\
\hline \multicolumn{4}{|l|}{ Hypertension } \\
\hline No & Ref & & \\
\hline Yes & & & 0.999 \\
\hline \multicolumn{4}{|l|}{ Tuberculosis } \\
\hline No & Ref & & \\
\hline Yes & & & 1.000 \\
\hline \multicolumn{4}{|l|}{ Sexually transmitted Diseases } \\
\hline No & Ref & & \\
\hline Yes & & & 1.000 \\
\hline \multicolumn{4}{|l|}{ Peptic ulcer } \\
\hline No & Ref & & \\
\hline Yes & & & 0.999 \\
\hline
\end{tabular}


Are you currently taking any medication

No

Ref

Yes

0.998

\section{Clinical characteristics}

Eyes affected

Right eye; oculus dexter

Left eye; oculus sinister

Ref

Both eyes; oculus uterque

0.47

$0.04-5.70$

0.555

Site of the eye affected

Eyelids/lashes

No

Ref

Yes

0.998

Conjunctiva

No

Ref

Yes

0.999

Cornea

No

Ref

Yes

0.36

$0.06-2.31$

0.282

Risk factors

Previous eye infections

No

Ref

Yes

0.19

$0.02-1.77$

0.145

Previous use of antimicrobials

No

Ref

Yes

0.998

Previous use of contact lens

No

Ref

Yes

1.000

Previous use of spectacles

No

Ref

Yes

0.46

$0.05-4.53$

0.505

Previous ocular trauma

No

Ref

Yes

0.998

Previous ocular surgery

No

Ref

Yes

0.999

Duration of illness
$<1$ week
Ref

2 - 4 weeks

0.998

$>4$ weeks

1.22

0.13-11.62

0.863

Previous application of mascara

No

Ref

Yes

0.999

Page 20/22 
Previous application of breastmilk

No Ref

Yes

0.999

Patient presenting symptoms

Eye pain

No

Yes

Ref

Itching

No

Yes

Ref

Yes

2.88

$0.31-26.70$

0.352

Falling lashes

No

Ref

Yes

1.000

Lacrimation/watering

No Ref

Yes

1.10

$0.18-6.89$

0.920

Hyperemia/redness

No

Ref

Yes

0.63

$0.07-5.84$

0.680

Swelling

No

Ref

Yes

0.998

Photophobia

No

Ref

Yes

0.32

$0.05-2.03$

0.315

Discharge

No

Ref

Yes

2.27

$0.36-14.21$

0.381

Burning sensation

No

Ref

Yes

0.999

Foreign body sensation

No

Ref

Yes

Others

0.999

No

Ref

Yes

0.56

$0.06-5.42$

0.615

$\mathrm{OR}$, Odds ratio; $\mathrm{Cl}$, confidence interval; Ref, Reference, Bivariate regression analysis at a significance of $\mathrm{p}<0.05$

\section{Figures}




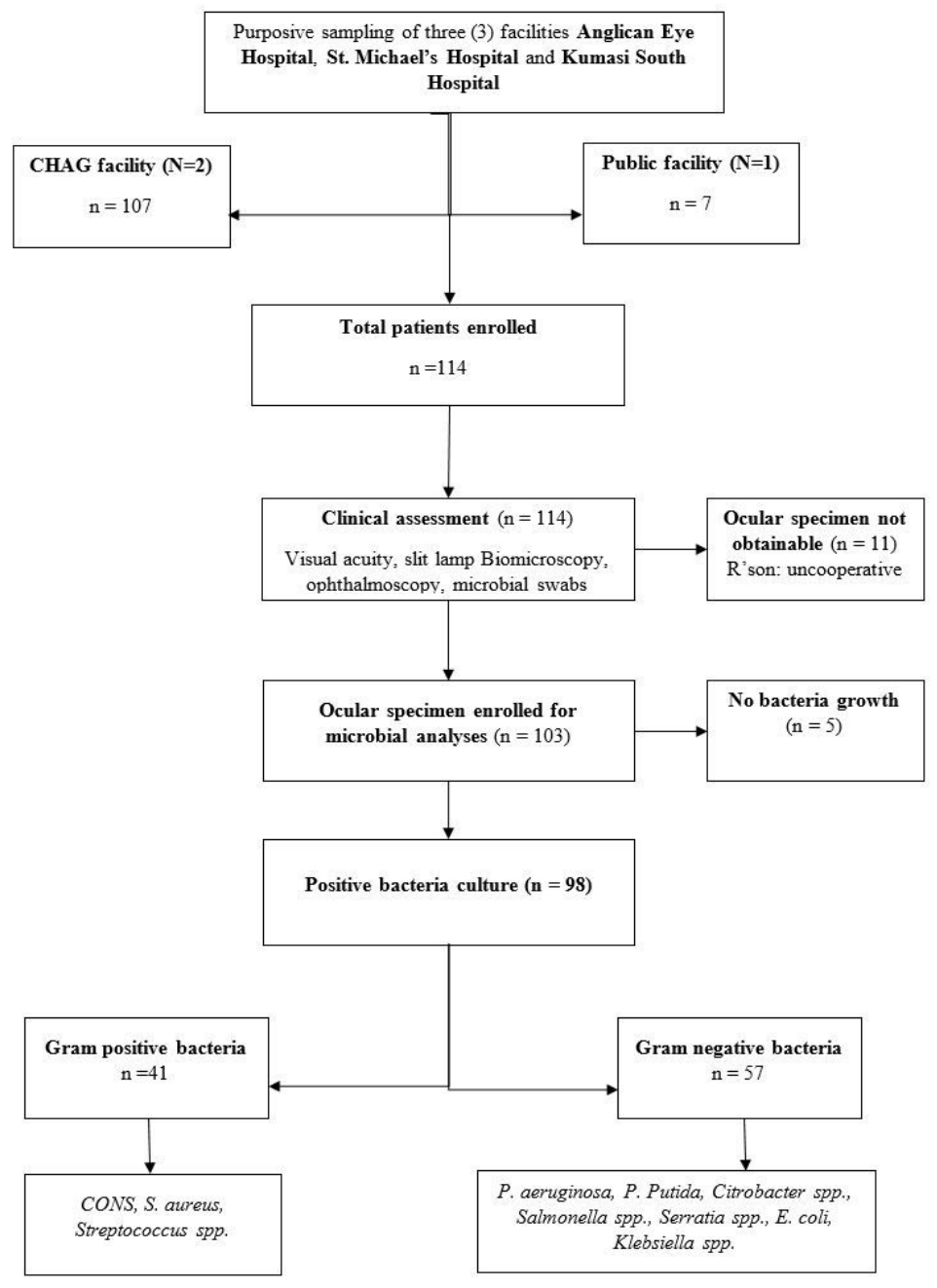

\section{Figure 1}

Flow diagram illustrating study methodology 